\title{
周波数変換法によるサージ入力波形推定における 誤差低減法の検討
}

\author{
正員 政 川俊 康 (三菱 電 機) \\ 非会員 笠 松 崇 彦 (スターネット) \\ 正員長岡直人 (同志社大)
}

\section{An Error Correction Method for an Input Waveform Estimate by Frequency Transform Method}

Toshiyasu Masakawa, Member (Mitsubishi Electric Corp.), Takahiko Kasamatsu, Non-member, (Star Net Corp.), Naoto Nagaoka, Member, (Doshisha University)

This paper clarifies a source for estimate error of an input voltage waveform of a capacitive voltage divider, when a frequency transform method is applied. From experimental and numerical analyses, an offset voltage of a digital waveform recorder causes significant error to an estimated voltage waveform. Because the offset voltage acts as DC. error, the effect of the offset is quite significant for an input wave which has more DC. component such as a switching surge waveform compared with a lightning surge.

An offset voltage correction method is proposed in this paper. This method is also applicable to the surge waveform is superposed upon a steady state sinusoidal voltage. Estimated inputs corrected by the proposed method show a good agreement with input voltage wave forms.

The input voltage-waveform estimation-method with the offset correction has quite high generality, and is applicable not only to lightning but also to switching surges.

キーワード：変歪誤差補正，周波数変換法，過渡現象，EMTP

\section{1. 緒言}

現代において，電気は我々の生活に久かすことのできな いエネルギーである。電力の安定供給のためには，事故を 未然に防ぐことが必要であるが，雷事故にみられるよう に，これを完全に零とすることは不可能である。そこで, 事故時に系統を早期に復旧することが望まれており，この ためには雷撃点あるいは事故点の標定を迅速に行う必要が ある。サージ波形による事故点標定は定常電生・電流によ る標定法と比して高速な判定が可能であるが，サージ波形 を精度良く測定することが必要である。しかしながら，高 精度なサージ電圧測定には良好な分圧周波数特性を有する 高価な分圧器が必要となる。そこで, 時間領域法あるいは 周波数領域法による数值計算により分珐特性を補正する手 法が考えられる。時間領域法は, 各時刻において分圧器の 単位関数応答あるいはインパルス応答と分圧器出力電圧に 畳込み積分を施すことにより得られる。各時間サンプルご とに数值積分を行う必要があるため，本質的に計算時間が 長くなる欠点を有する。周波数領域法の一つである周波数
変換法は，周波数領域において直接分圧器の周波数特性を 補正する。これには，時間-周波数変換に積分変換である 数值フーリエあるいは数値ラプラス変換を要するが, FFTのアルゴリズムを導入することにより，高速に積分 を実行しうる。更に，周波数領域により処理することによ り, 分圧器の周波数特性が実測などにより知られる場合 は，等価回路が明らかでない場合にも適用しうる特徴を有 する。

著者らはこれまで，商用周波数電圧の監視を目的として 変電所に設置されている安価なコンデンサ形分圧器 (CVT) の変歪した出力波形より，周波数変換法を用いて サージ入力波形を推定する手法について研究を行ってき た (1) (5)。本手法によれば, 極めて経済的にサージ波形測 定を行うことが可能となる。

この手法は雷サージ波形など極めて高い周波数成分を有 する波形に対しては有効であり，実用性も高い。しかしな がら観測時間が長く，比較的低い周波数成分を有する波 形, 例えば開閉サージの入力波形推定においては, 推定精

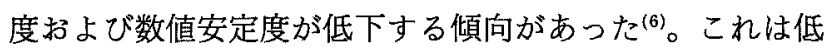


周波に対するCVTの分圧比が大であることにより， CVT 出力波形に含まれる低周波成分が極めて小であるこ とによる。すなうち，入力推定においては小なる低周波成 分を増幅し，入力波形を合成する必要があるため，わずか な誤差が入力推定に大なる影響を及ぼす。

本論文では，CVTスケールモデルによる実験結果を基 に，開閉サージ入力波形推定時の誤差原因を明らかにす る。更に，この推定誤差を低減する手法について述心，雷 サージに加え従来困難であった開閉サージ入力波形推定を 実行しうるシステムを実現する。

\section{2. 周波数变換法を用いた入力信号推定}

〈2・1〉入力推定の原理 CVTをはじめとする二端 子対回路網の出力信号波形加ら入信号波形を推定する一 手法として，周波数変換法による数値計算法がある。その 原理について以下に述べる(7) -(9)。

入力信号および出力信号を $v_{\mathrm{in}}(t), v_{\mathrm{out}}(t)$ とする。回路 の特性が線形時不変であると仮定すると，これらの関係は 周波数領域で求式で与えられる。

$V_{\text {out }}(s)=F(s) V_{\text {in }}(s)$

ここで, $V_{\mathrm{in}}(s)=\mathscr{L} v_{\mathrm{n}}(t)$ : 入力信号周波数応答, $V_{\text {out }}(s)=\mathscr{L} v_{\text {out }}(t)$ : 出力信号周波数応答, $F(s)$ :

周波数領域伝達関数, $\mathscr{L}:$ : プラス・フーリエ順 変換

従って, 入力信号推定は伝達関数 $F(s)$ の逆関数 $G(s)$ を求め，(1)式の逆演算を実行することにより実現でき る。この $G(s)$ は伝送関数と呼ばれる。

$$
\begin{aligned}
& G(s)=1 / F(s) \\
& =V_{\text {in }}(s) / V_{\text {out }}(s) \\
& V_{\text {in }}(s)=G(s) V_{\text {out }}(s) \text {. } \\
& v_{\text {in }}(t)=\mathscr{L}^{-1} V_{\text {in }}(s) \\
& \text { ここで, } \mathscr{L}^{-1} \text { : ラプラス・フーリ工逆変換 }
\end{aligned}
$$

(2)，（3）式に示す計算を数值的に行う場合，離散順逆 変換の精度が問題となる。本論文では，順変換として折返 し誤差を生じない直線近似ラプラス変換 $(\mathrm{LLT})^{(10)(1)}$ を, 逆変換として LLTと良好な変換対をなす高速逆ラプラス

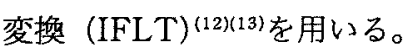

実測により得られる出力信号は測定時の雑音を含む。更 に，近年過渡現象測定に用いられるディジタルサンプリン グ波形記憶装置は，量子化誤差および大地電压レベルのず れ（以下，オフセットと呼ぶ）を含む。これらはいずれも 入力波形推定時に誤差原因となる。

〈2・2〉 CVTスケールモデルの入力推定 実測データ に対する入力波形推定の精度を検討するため，図 1 に示す CVT スケールモデルを製作し，伝送関数 $G(s)$ をラプラ ス演算子 $s$ の有理関数モデルを用いて入力波形を推定し た。モデル回路における $C_{1}$ と $C_{2}$ はコンデンサ形分圧器 を構成する。 $L_{2}$ と $R_{2}$ は漂遊インダクタンスおよび導線抵 抗でその值は小であるが, 大なる $C_{2}$ との直列共振周波数 が比較的低くなるため，分圧比の周波数特性に大きな影響

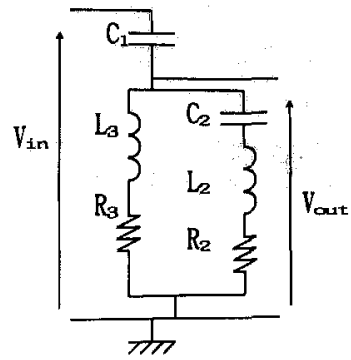

図 1 CVT モデル

Fig. 1. A model of CVT.

表 1 CVT モデル定数

Table 1. Ciruit parameters of the CVT model.

\begin{tabular}{l|c|c}
\hline & モデル1 & モデル2 \\
\hline$C_{1}$ & $0.022 \mu \mathrm{F}$ & $0.22 \mu \mathrm{F}$ \\
$C_{2}$ & $2 \mu \mathrm{F}$ & $2 \mu \mathrm{F}$ \\
$R_{2}$ & $65 \mathrm{~m} \Omega$ & $65 \mathrm{~m} \Omega$ \\
$R_{3}$ & $32 \Omega$ & variable \\
$L_{2}$ & $0.36 \mu \mathrm{H}$ & $0.36 \mu \mathrm{H}$ \\
$L_{3}$ & $20 \mathrm{mH}$ & $20 \mathrm{mH}$ \\
\hline
\end{tabular}

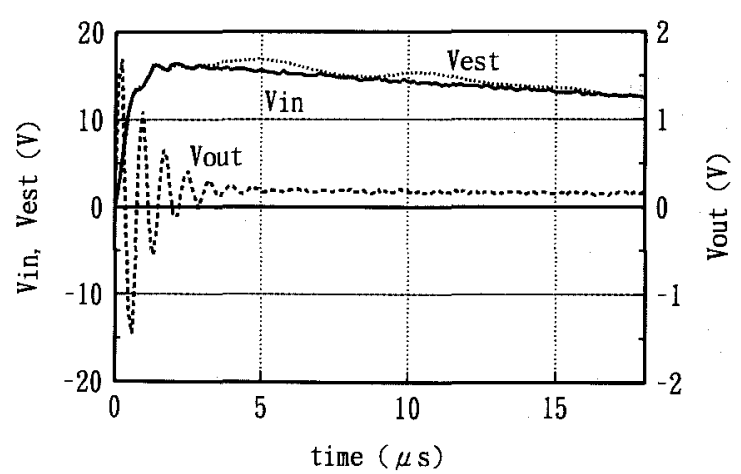

図 2 雷サージ波形推定結果

Fig. 2. A result for a lightning surge.

を及ぼす。 $L_{3}, R_{3}$ はドレーンコイルのインダクタンスおよ びその巻線抵抗を表現する。 $C_{2}$ と $L_{3}$ に上る並列共振周波 数はさきの直列共振周波数より低く, 更に $L_{3}$ が出力端子 に対して並列接続されるため，低周波成分に対しては $L_{3}$ が大なる影響を及ぽす。各回路定数設定值を表 1 に示す。

電源として標準雷インパルスを表 1 のモデル 1 に示す定 数を有するCVT モデルに印加した場合の入出力波形 $V_{\mathrm{in}}$, $V_{\text {out }}$ および推定結果 $V_{\text {est }}$ を図 2 に示す。出力電圧は $C_{2}$ と $L_{2}$ の共振により, 波頭部において高周波振動が観測され るが，これより得られる入力波形推定結果は入力波形と良 好に一致している。特に，高周波成分により定まる波頭部 においては誤差はほとんど観測されない。波頭部と比べて 低周波成分が支配的となる平坦部では若干の差異が観測さ れるが，本例に見られるような最大観測時間が数十 $\mu \mathrm{s}$ 程 度の雷サージ波形に対しては，周波数変換法による推定結 果恃入力波形に良好に一致している。

これに対し，最大観測時間を $10 \mathrm{~ms}$ 程度とし，単位関 数状の電圧をモデル 1 に印加した場合の入出力波形および 


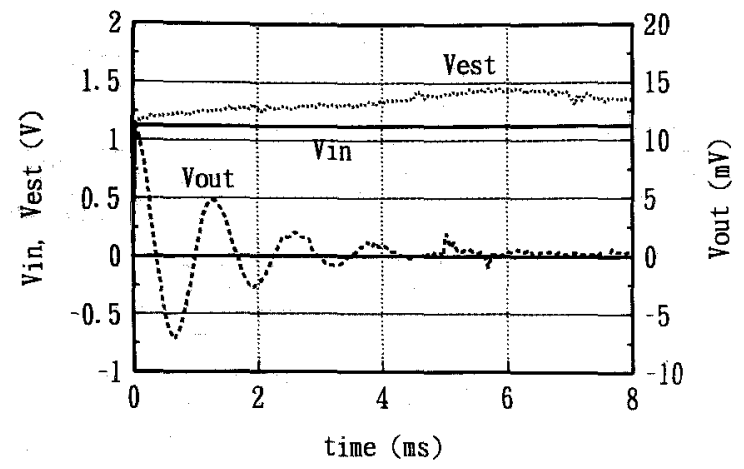

図 3 開閉サージ推定結果

Fig. 3. A result for a switching surge.

入力推定結果を図 3 に示す。出力波形は $L_{3}$ と $C_{2}$ の共振 により，750 Hz 程度の正弦波状の振動が観測されるが， 推定結果にはこの振動は観測されない。高周波成分が支配 的である波頭部の推定精度は高いものの, 時間の経過につ れて精度が低下することが明らかである。この一因に， CVT 等価回路定数すなわち伝送関数 $G(s)$ の精度が考え られる。雷サージと比較して, 開閉サージに対しては低周 波成分が大なる影響を及ぼすため, 図 1 における $C_{2}, L_{3}$, $R_{3}$ の定数設定には注意を要する。実機において，これら の素子定数はブリッジなどで比較的精度良く測定ができる うえ, 図 3 における出力波形の振動周期および減衰からも 容易に求めうる ${ }^{(4)}$ 。後者により求めた定数の精度は波形測 定の精度に依存するが，ディジタルサンプリングを用いた 波形測定によれば読取誤差を低減し，十分な精度で定数を 求めうる。しかしながら，回路定数の䛊差を極力小として も，図 3 に示す入力波形とその推定值の差異は依然観測さ れる。周波数変換法による CVT 開閉サージ入力波形推定 を実用性の高いものとするためにはこの原因を解明し，推 定精度を改善することが必要である。

\section{3. オフセットの補正}

〈3・1〉オフセットの影響ステップ入力波形推定時 の誤差原因を明らかにするため, 図 1 に示す回路の $C_{1}$ を $0.22 \mu \mathrm{F}$ とし，R $R_{3}$ 可変とした場合（モデル2）につい て同様に入力推定を行った。 $R_{3}$ が小となるに伴い入力推 定の精度は悪化し，推定誤差の絶対値はいずれの場合も時 間経過に伴って増加することが明らかとなった。例とし て， $R_{3}$ を $32 \Omega, 500 \Omega$ とした場合の入力推定結果をそれ ぞれ図 4 に示す。

$C_{2}$ と $L_{3}$ の共振による振動は $R_{3}$ が約 $190 \Omega$ で臨界的と なる。R $R_{3}$ が大となるにつれて出力波形㥗振動性から減衰 性へと変化し, 出力波形に含まれる直流成分は次第に増加 する。図 4 より，出力波形に含まれる直流成分が小となる と，推定誤差が増大することが観測される。なお，出力波 形を解析的に計算し，これより入力推定を行った埸合誤差 は観測されず，図 3, 図 4 に示す誤差は害測波形を用いた とき特有の現象である。すなわち，出力に含まれる直流成分

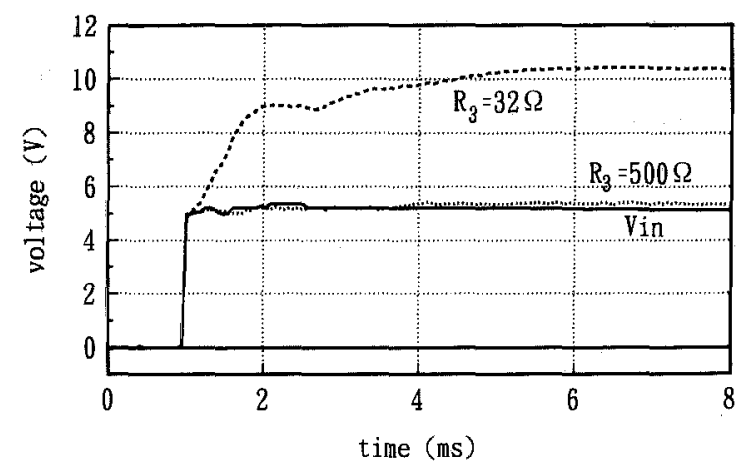

図 $4 \quad R_{3}$ による推定誤差の影響

Fig. 4. Effects of $R_{3}$ on estimation error.

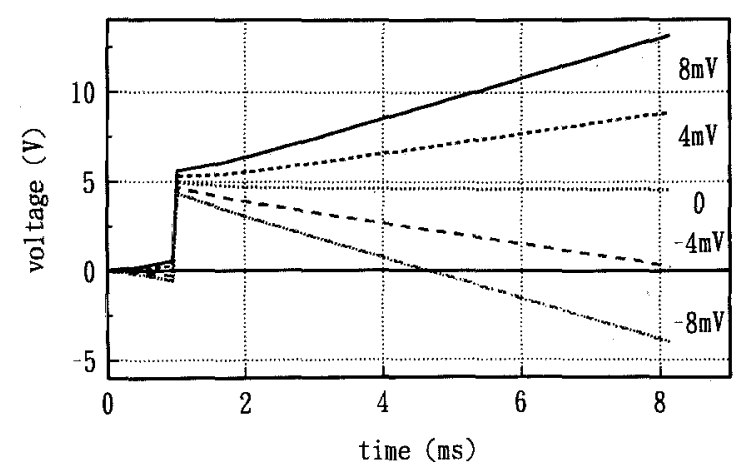

図 5 オフセット電圧による推定誤差の影響

Fig. 5. Effects of offset voltage on estimation error.

が小である振動性の場合出力信号測定值に混入する直流誤 差の相対量が増大するため，推定誤差が大となると推論で きる。CVTの変歪誤差補正を高精度に実行するために は, CVT 分压回路内のドレーンコイル抵抗 $R_{3}$ を増加さ せればよい。しかしながら， $R_{3}$ を增加させると $C_{2}$ の放電 に要する時間が大となるため， $R_{3}$ の上限は制限を受ける。

実測時に混入する直流誤差の主因はオフセットである。 何らかの原因で出力波形の大地電圧レベルがずれて記録さ れていた場合, 記録された波形は実際の波形にオフセット 分の直流が重疊したものとなる。また，記録に伴う波形の 量子化によっても，最小分解能以下の情報が失われるため 直流成分に同様な誤差を生じる。

オフセットが入力推定結果に与える影響を検討するた め, コンピュータ上で入力推定のシミュレーションを行っ た。図 2 に示す回路に振幅 $5 \mathrm{~V}$ を有する単位関数電圧を 入力したときの出力波形を解析的に計算し，オフセットの 影響を調查するため直流成分を種々加えて入力波形を推定 する。この結果を図 5 に示す。同図より，オフセットによ る推定誤差は波頭部におでて小であり，平坦部で大となる 傾向を有する。この結果より，最大観測時間が大なる場合 の入力推定誤差の一因はオフセットであることが明らかと なった。

また，時刻 $6 \mathrm{~ms}$ に扔ける推定誤差とオフセット值との 関係を図 6 に示す。同図より推定誤差はオフセット值とほ 


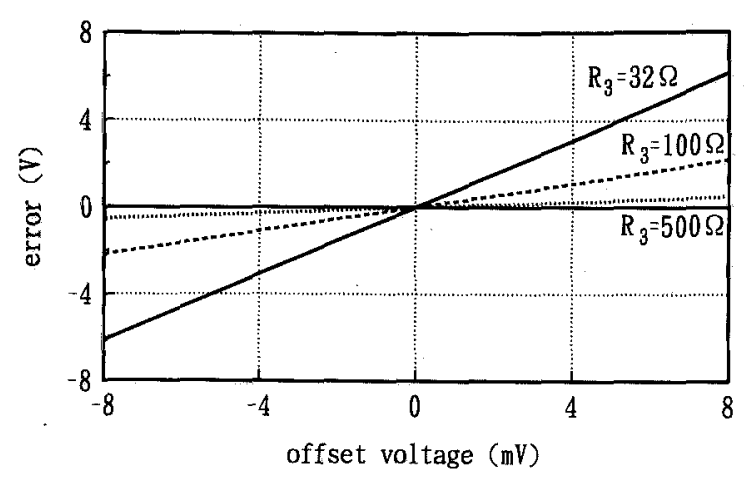

図 6 誝差一オフセット電圧特性

Fig. 6. Error vs. offset voltage characteristics.

济比例関係にある。この理由は以下のように説明できる。

出力信号 $v_{\text {out }}(t)$ にオフセット の周波数応答も以下のように変化する。

$$
\begin{aligned}
& v_{\text {out }}{ }^{\prime}(t)=v_{\text {out }}(t)+\varepsilon \\
& V_{\text {out }}{ }^{\prime}(s)=V_{\text {out }}(s)+\varepsilon / s \\
& \text { ここで, } V_{\text {out }}{ }^{\prime}(t): \text { オセットを付加した出力信 } \\
& \text { 号, } V_{\text {out }}{ }^{\prime}(s): v_{\text {out }}{ }^{\prime}(t) \text { の周波数応答 }
\end{aligned}
$$

この出力信号より (3) 式を用いて入力推定を行うと以下と なる。

$$
\begin{aligned}
& \begin{aligned}
V_{\mathrm{est}}(s) & =G(s) V_{\text {out }}{ }^{\prime}(s) \\
& =G(s)\left\{V_{\text {out }}(s)+\varepsilon / s\right\} \\
& =V_{\text {In }}(s)+\varepsilon G(s) / s \\
& =V_{i}(s)+\varepsilon H(s) \quad \ldots \ldots \\
v_{\text {est }}(t) & =V_{\text {in }}(t)+\varepsilon \mathscr{L}^{-1} H(s) \\
& =V_{\text {in }}(t)+\varepsilon h(t) \ldots \ldots \ldots . .
\end{aligned} \\
& \begin{aligned}
V_{\mathrm{est}}(s) & =G(s) V_{\text {out }}{ }^{\prime}(s) \\
& =G(s)\left\{V_{\text {out }}(s)+\varepsilon / s\right\} \\
& =V_{\text {In }}(s)+\varepsilon G(s) / s \\
& =V_{i}(s)+\varepsilon H(s) \quad \ldots \ldots \\
v_{\text {est }}(t) & =V_{\text {in }}(t)+\varepsilon \mathscr{L}^{-1} H(s) \\
& =V_{\text {in }}(t)+\varepsilon h(t) \ldots \ldots \ldots . .
\end{aligned} \\
& \begin{aligned}
V_{\mathrm{est}}(s) & =G(s) V_{\text {out }}{ }^{\prime}(s) \\
& =G(s)\left\{V_{\text {out }}(s)+\varepsilon / s\right\} \\
& =V_{\text {In }}(s)+\varepsilon G(s) / s \\
& =V_{i}(s)+\varepsilon H(s) \quad \ldots \ldots \\
v_{\text {est }}(t) & =V_{\text {in }}(t)+\varepsilon \mathscr{L}^{-1} H(s) \\
& =V_{\text {in }}(t)+\varepsilon h(t) \ldots \ldots \ldots . .
\end{aligned} \\
& \begin{aligned}
V_{\mathrm{est}}(s) & =G(s) V_{\text {out }}{ }^{\prime}(s) \\
& =G(s)\left\{V_{\text {out }}(s)+\varepsilon / s\right\} \\
& =V_{\text {In }}(s)+\varepsilon G(s) / s \\
& =V_{i}(s)+\varepsilon H(s) \quad \ldots \ldots \\
v_{\text {est }}(t) & =V_{\text {in }}(t)+\varepsilon \mathscr{L}^{-1} H(s) \\
& =V_{\text {in }}(t)+\varepsilon h(t) \ldots \ldots \ldots . .
\end{aligned} \\
& \begin{aligned}
V_{\mathrm{est}}(s) & =G(s) V_{\text {out }}{ }^{\prime}(s) \\
& =G(s)\left\{V_{\text {out }}(s)+\varepsilon / s\right\} \\
& =V_{\text {In }}(s)+\varepsilon G(s) / s \\
& =V_{i}(s)+\varepsilon H(s) \quad \ldots \ldots \\
v_{\text {est }}(t) & =V_{\text {in }}(t)+\varepsilon \mathscr{L}^{-1} H(s) \\
& =V_{\text {in }}(t)+\varepsilon h(t) \ldots \ldots \ldots . .
\end{aligned} \\
& \begin{aligned}
V_{\mathrm{est}}(s) & =G(s) V_{\text {out }}{ }^{\prime}(s) \\
& =G(s)\left\{V_{\text {out }}(s)+\varepsilon / s\right\} \\
& =V_{\text {In }}(s)+\varepsilon G(s) / s \\
& =V_{i}(s)+\varepsilon H(s) \quad \ldots \ldots \\
v_{\text {est }}(t) & =V_{\text {in }}(t)+\varepsilon \mathscr{L}^{-1} H(s) \\
& =V_{\text {in }}(t)+\varepsilon h(t) \ldots \ldots \ldots . .
\end{aligned}
\end{aligned}
$$

(8)式の第 2 項はオフセットに起因する推定誤差を表し ている。すなわち, ラプラス変換の線形性より推定詰差は オフセットに比例することがわかる。また，特に図１に示 す回路の場合, 漂遊インダクタンスおよび微小抵抗を無視 すると, $H(s)$ の時間応答 $h(t)$ は以下となる。

$$
\begin{aligned}
h(t)= & \left(C_{1}+C_{2}\right) / C_{1}-L_{3} / C_{1} R_{3}{ }^{2}+t / C_{1} R_{3} \\
& +\left(L_{3} / C_{1} R_{3}{ }^{2}\right) \exp \left(-R_{3} t / L_{3}\right) \cdots \cdots
\end{aligned}
$$

(9)式は時間に比例する項と指数的に減衰する項を有す る。従って，十分に時間が経過すれば前項が支配的とな り，オフセットによる誤差は時間の増大とともに増加する ことが明らかである。更に $C_{1}, R_{3}$ が増大すれば，この誤 差が小となることも容易に知られる。これらの誤差特性は 図 5 に見られる特性と一致している。

〈3・2〉 オフセット補正 前節での検討により, 出力 信号のオフセットが入力推定結果に与える影響が明らかと なった。次に問題となるのは, 出力に含まれるオフセット の值を推定する手法である。オフセットの值が推定できれ ば，その值を出力信号から差し引くことによって精度の高 い入力推定を実行し得る。

オフセットの補正は，入力信号に何の制約条件も含まな い一般の場合には極めて困難である。しかし, 推定対象を

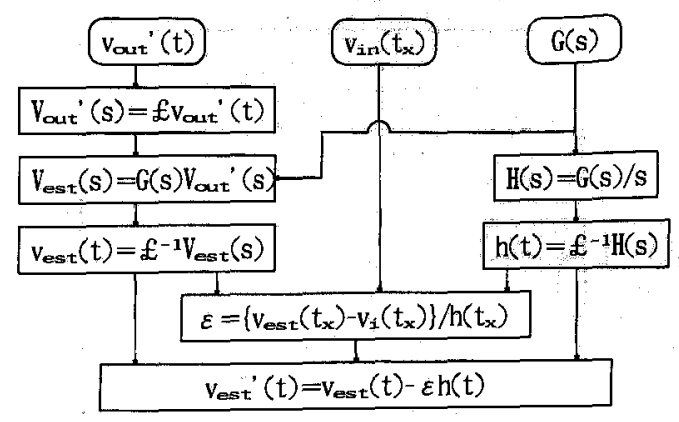

図 7 オフセット補正フロー図

Fig. 7. A flowchart of the proposed offset correction method.

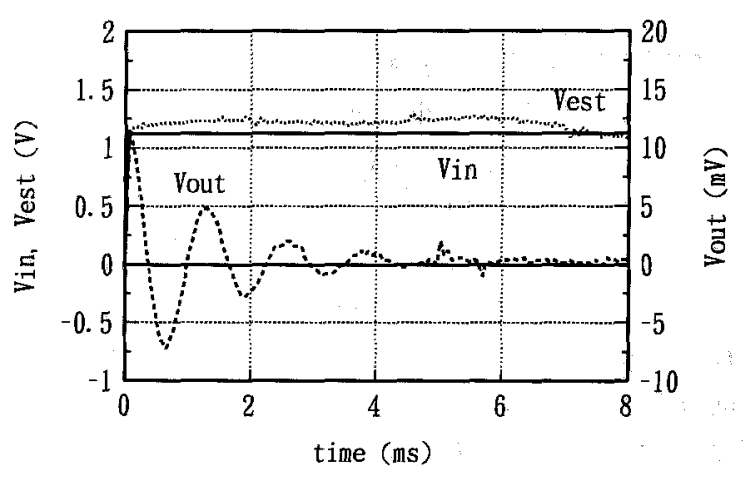

図 8 オフセット補正を施した入力 推定波形

Fig. 8. An estimated input waveform applying the offset correction method.

電力系統のサージ電圧波形に限定すれば，その入力波形が 有すると考えられる条件を仮定することによりオフセット を補正することが可能である。サージ現象は十分に時間が 経過すれば零に収束するため, 観測時間後半の入力值は容 易に求め得る。オフセットをを含むCVT出力信号を $v_{\text {out }}(t)$ とすると $(7)$ ，(8)式により愦差を含む推定結果 $v_{\text {est }}(t)$ が得られる。ある時刻 $t=t_{x}$ における入力 $v_{\text {in }}\left(t_{x}\right)$ が明らかである場合， $\varepsilon$ は ( 8) 式より求めうる。

$$
\varepsilon=\left\{v_{\mathrm{est}}\left(t_{x}\right)-v_{\mathrm{In}}\left(t_{x}\right)\right\} / h\left(t_{x}\right) \cdots
$$

すなわち，オフセット誤差を消去した入力推定值 $v_{\text {est }}{ }^{\prime}(t)$ は (8)，(10)式より次式で与えられる。

$$
v_{\text {est }}{ }^{\prime}(t)=v_{\text {est }}(t)-\left\{v_{\text {est }}\left(t_{x}\right)-v_{\mathrm{in}}\left(t_{x}\right)\right\} h(t) / h\left(t_{x}\right)
$$

なお，測定值 $v_{\text {out }}{ }^{\prime}(t)$ に雑音が混入している場合は $t_{x}$ 複数点与え，(10)式に示す演算を行い，その平均值により $\varepsilon$ をえればよい。本論文で提案するオフセット補正法の フロー図を図7 に示す。

図3に示す例（モデル 1) において最大観測時間におけ る入力值 $(=1.21 \mathrm{~V})$ を仮定し，オフセットを修正して 入力波形推定を行った例を図 8 に示す。本例においては (10)式における $t_{x}$ を約 $8 \mathrm{~ms}$ としているため，この時刻近 傍における推定精度は高い。時刻 $5 \mathrm{~ms}$ 近傍で観測される 出力電圧波形に雑音がみられるにもかかわらず, 推定結果 はオフセット補正を行わない場合（図 3 ）に比して誤差を 
$1 / 2$ 程度低減している。これより，本論文で提案するオフ セット補正法は, 雑音に対しても安定であることが明らか である。

〈3-3〉周期性定常解を用いたオフセット推定 図 7 に示すように，オフセット補正值を求めるためにある時刻 $t_{x}$ の真の入力電圧を知る必要がある。入力電圧波形がイ ンパルス状であることが明らかであれば，十分時間が経過 した時刻の值が零となることより， $v_{\text {in }}\left(t_{x}\right)=0$ として実行 すればよい。しかし，電力系統の電圧測定においては，入 力電圧は商用周波数交流電圧が重畳している場合が考えら れる。この場合, ある時刻における真の入力電圧を知るこ とは困難であるが，例えば充電線路に開閉サージが重畺し た場合，時間が十分に経過した後の CVT 入力電圧 $v_{\mathrm{ln}}(t)$ は商用周波数 $f_{c}$ の振動を有すると考えられる。この周期 性を利用すれば，前述の時刻 $t_{x}$ における入力值 $v_{\text {in }}\left(t_{x}\right)$ を 与えることなく，自動的にオフセット補正を行うことがで きる。過渡現象が十分に減衰した時刻を $t_{x}$ とすると，才 フセット誤差を含む CVT 出力電圧により入力を推定した 結果は $(8)$ 式により得られる。

$$
\left.\begin{array}{l}
v_{\text {est }}\left(t_{x}\right)=v_{\text {in }}\left(t_{x}\right)+\varepsilon h\left(t_{x}\right) \\
v_{\text {est }}\left(t_{x}+T\right)=v_{\text {in }}\left(t_{x}+T\right)+\varepsilon h\left(t_{x}+T\right)
\end{array}\right\}
$$

入力波形の周期性を仮定すれば(12)各式の差よりオフセッ ト $\varepsilon$ が得られる。

$$
\begin{array}{r}
\epsilon=\left\{v_{\text {est }}\left(t_{x}\right)-v_{\text {est }}\left(t_{x}+T\right)\right\} /\left\{h\left(t_{x}\right)-h\left(t_{x}+T\right)\right\} \\
\because v_{\text {in }}\left(t_{x}\right)=v_{\text {in }}\left(t_{x}+T\right) \cdots \ldots \ldots \ldots \ldots \ldots \ldots \ldots \ldots \ldots \ldots
\end{array}
$$

図 9 に送電線を L 型等価回路 2 段で表現した CVT を含 む投入サージモデル回路を示す。図中の $L_{0}$ は線路インダ クタンスと変圧器漏れインダクタンスを表現する。スイッ チを閉じたときの，線路終端に接続したCVT 出力電圧よ り入力推定を行った結果を図 10 に示す。出力電圧は

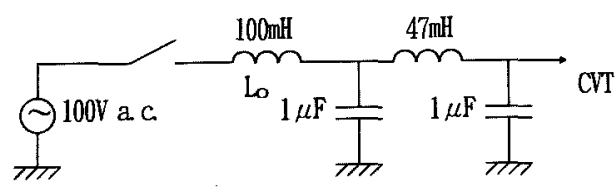

図 9 投入サージモデル回路

Fig. 9. An model circuit for switching surge.

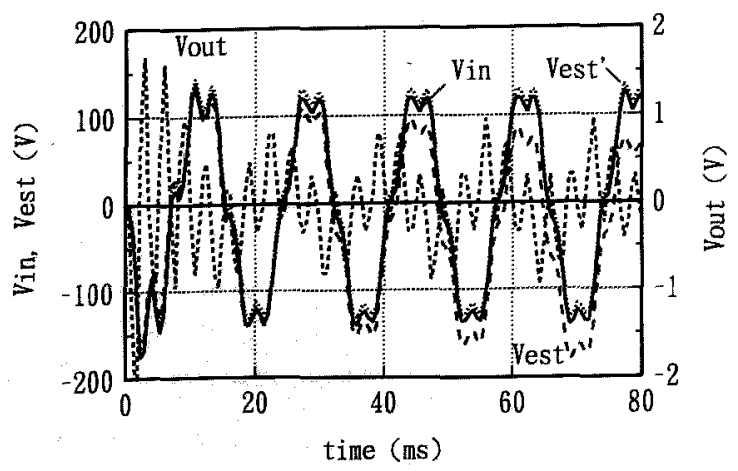

図 10 投入サージ推定結果

Fig. 10. Estimated inputs for switching surge.
CVT 内の共振により，高周波の振動が観測される。図に おいて， $V_{\text {est }}$ は本論文で提案したオフセット補正法を適用 しなかった場合の推定結果， $V_{\text {est }}{ }^{\prime}$ は提案法を適用した結 果である。図から，オフセット誤差により $V_{\text {est }}$ は〈3・1〉節 に示すように，発散傾向を示すことが明らかである。本節 で提案した周期性を仮定したオフセット補正法により入力 推定した結果 $V_{\mathrm{est}}{ }^{\prime}$ は極めて良好に入力波形を表現してい ることが明らかである。なお，(13)式によるオフセット修 正は周期定常解に収束する場合のみでなく，Tを適当な 時間間隔にとることにより，直流定常解に収束する場合に も適用しうる。

\section{4. 結言}

本論文では, 安価な分圧器の変昰した出力波形より入力 波形を推定する変歪誤差補正の誤差の主因が，測定時に混 入するオフセット詿差であることを明らかにした。更に， 周波数変投法による変歪誤差補正に扔いてオフセットを修 正し，入力推定を高精度に行う手法を開発した。本手法 は，これまで困難であった開閉サージなどの此較的低周波 成分を有する入力波形推定を可能とし，コンピュータを用 いた分圧器変歪誤差補正システムの実用性の向上および適 用範囲の拡大に寄与する。更に本手法は, 高電圧測定のみ ならず，多様な分野に応用可能であると考えられる。

最後に, 本研究をすすめるにあたり貴重な御助言を賜つ た関西電力 (株), 日新電気(株)の関係者各位および本学 雨谷昭弘教授に謝意を表する。

(平成 5 年 6 月 4 日受付)

\section{文献}

（1）長岡·松川：「雷サージに対するCVT 分圧応答特性の検討 第 1 報数值ラプラス変換による誤差補正」, 平 2 電気関係学会関西 支部連大, G4-38

（2）政川・長岡・松川：「雷サージに対するCVT 分圧応答特性の検 討 第 2 報集中定数回路」, 平 2 同上, G4-39

（3）政川・長岡・松川：「雷サージに対するCVT 分圧応答特性の検 討第 3 報 $Z$ 変換による変歪器差補正」, 平 3 電気学会全大, No. 1239

（4）政川·長岡：「分圧器出力波形変歪誤差補正法に関する一検討」, 電気学会電力技術研資, PE-91-49 (平 3)

（5）政川・長岡：「開閉サー沙に対するCVT 入力波形変㤠誤差補正 法の検討」, 平 4 電気学会全大, No. 1203

（6）政川・笠松・長岡：「入力波形推定に扔ける誤差低減法の検討 第 1 報オフセットの補正法」, 平 4 電気関係学会関西支部達大, G4-9

(7) A. Pappoulis: Signal analysis, p. 92 (1977) McGraw-Hill Inc.

（8）瀧：伝送回路学（第 2 版），p. 75 (昭 53）共立出版

(9) W. H. Chen: Linear network design and synthesis, p. 45 (1964) McGraw-Hill, Inc.

（10）長岡・雨谷：「薄線近似フーリエ・ラプラス䐓変換」，第 2 回ソフ トウェアコンファレンス (昭 61)

(11) N. Nagaoka \& A. Ametani: "A development of a generalized frequency-domain transient analysis program-FTP", IEEE Trans. PWRD, PWRD-3, 1996 (1988)

(12) A. Ametani : "The application of the tast Fourier transform to electrical transients phenomena", Int. J. Elect. Eng. Educ., 10, 277 (1973)

(13) D. J. Wilcox: "Numerical Caplace transformationan and Inversion", ibid., 15, 247 (1978)

(14) W. S. Meyer : EMTP rule book (1984) B.P.A. 
政 川 俊 康 (正員) 1967 年 12 月 23 日生。1991 年 3 月同志 社大学工学部電子工学科卒業。1993 年 3 月同志 大学大学院電気工学専攻博士課程前期修了。同 年 4 月三菱電機 (株) 入社。情報システム研究所 にて音声合成技術の研究に従事。
長 岡 直人（正員） 1957 年 10 月 21 日生。1982 年同志社大 学工学部電気工学尃攻博士課程前期修了。1985 年 4 月同大学工学部電気工学科助手, 1988 年同 講師, 1992 年同助教授, 現在に至る。主とし て, 電力系統に発生する過渡現象シミュレーシ ヨンおよび数値計算モデルの開発に従事。

IEEE, 電子情報通信学会, 電気設備学会会員。

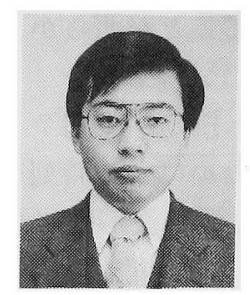

笠 松 崇 彦 (非会員) 1969 年 3 月 22 日生。1993 年 3 月同 志社大学工学部電子工学科卒業。同年 4 月ス夕 ーネット (株) 入社。同社システム技術部にて通 信ネットワークに用いる交換機の保守・運用に従

事。

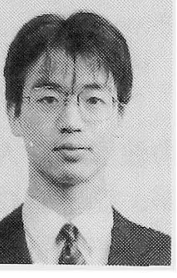

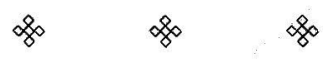

